\title{
Does Removing Coyotes for Livestock Protection Benefit Free-Ranging Ungulates?
}

\author{
JUSTIN L. HARRINGTON, Jack H. Berryman Institute, Department of Wildland Resources, Utah State University, Logan, UT 84322-5270, USA \\ MICHAEL R. CONOVER, ${ }^{1}$ Jack H. Berryman Institute, Department of Wildland Resources, Utah State University, Logan, UT 84322-5270, USA
}

\begin{abstract}
We studied the effects of coyote (Canis latrans) control for livestock protection on native ungulates during 2003 and 2004 on 7 sites in Utah and Colorado, USA, totaling over $1,900 \mathrm{~km}^{2}$. We found no relationships between coyote control variables and offspring/female deer ratios. However, control effort (no. of hr spent aerial gunning for coyotes) and success (no. of coyotes taken) were positively correlated with numbers of mule deer (Odocoileus hemionus) and pronghorn (Antilocapra americana) observed per kilometer of transect. Our results suggest that coyote control for livestock protection may increase densities of mule deer and pronghorn in areas where it is conducted. (JOURNAL OF WILDLIFE MANAGEMENT 71(5):1555-1560; 2007)
\end{abstract}

DOI: $10.2193 / 2006-481$

KEY WORDS aerial gunning, Antilocapra americana, Canis latrans, coyote control, mule deer, Odocoileus hemionus, predator control, pronghorn, wildlife damage management.

Mule deer (Odocoileus hemionus) are an important big-game species in the western United States, but their populations are highly volatile and difficult to regulate (Denney 1976, Parsons 1976, Fuller 1998, Mackie et al. 1998). Mule deer populations have declined in many parts of the West, and the reasons for the decline are uncertain and vary across areas (Ballard et al. 2001, deVos et al. 2003). Severe winters in the northern part of their range, droughts in arid regions, loss of critical winter habitat due to development, habitat changes, competition with elk (Cervus elaphus), and predation on deer offspring have all been identified as possible reasons for the decline in some areas (deVos et al. 2003).

After reviewing literature on effects of predation on native ungulates, Connolly (1978) concluded that 45 studies indicated predation was a limiting factor, whereas 27 studies did not. However, the level of documentation reported in these studies varied widely, and a selective review of the literature could reinforce almost any view on the role of predation on wildlife (Connolly 1978). Hence, the role of predation on limiting and regulating mule deer populations remains unclear (Ballard et al. 2001, 2003).

In parts of the West, coyote (Canis latrans) predation is the greatest source of mortality of pronghorn (Antilocapra americana) offspring (Barrett 1984, Smith et al. 1986, Gregg et al. 2001). In areas where pronghorn densities are low and beneath carrying capacity, coyote control has produced an increase in offspring survival and pronghorn densities (Smith et al. 1986, Phillips and White 2003). Some western states, such as Utah, have contracted with the United States Department of Agriculture, Animal Plant Health Inspection Services, Wildlife Services to control coyotes in areas where pronghorn offspring:female ratios are below the management objectives of state wildlife agencies (M. Bodenchuk, Wildlife Services [WS], personal communication).

Still, it is unclear if predator control would increase mule

${ }^{1}$ E-mail: conover@cc.usu.edu deer and pronghorn densities or offspring survival because there have been few well-designed experiments on the subject (Gill 2001), and none have examined effects of predator control implemented on areas $>1,000 \mathrm{~km}^{2}$ (Ballard et al. 2003). We conducted a large-scale study covering over areas $>1,900 \mathrm{~km}^{2}$ in Utah and Colorado, USA, to determine whether the level of predator control conducted for livestock protection was related to observed mule deer or pronghorn densities and offspring:female ratios.

\section{STUDY AREA}

We conducted our study on 7 sites comprising approximately $650 \mathrm{~km}^{2}$ (Fig. 1) in northeastern Utah (Diamond Mountain-Coyote Basin) and $>1,250 \mathrm{~km}^{2}$ in northwestern Colorado (Blue Mountain, Douglas Pass, Douglas Mountain, Meeker, Great Divide North, and Great Divide South). In Utah, boundaries for Diamond MountainCoyote Basin site were the same as Utah Division of Wildlife Resources (UDWR) hunting units with the same names. In Colorado, Blue Mountain consisted of Colorado Division of Wildlife's (CDOW) Game Management Unit (GMU) 10 combined with $<20 \mathrm{~km}^{2}$ of adjacent land in Utah. The Douglas Pass site was centered on the southern boundary of GMU 21, the northern boundary of GMU 30, and extended $10 \mathrm{~km}$ inside each of these units. Douglas Mountain composed the portion of GMU 2 south of State Route 318. The Meeker site was located on the southern and eastern sides of GMU 11 where it bordered GMU 211, 22, and 23; this site extended approximately $20 \mathrm{~km}$ to either side of this border. Great Divide North was located in the northern $30 \%$ of GMU 3 and included a small portion $\left(<10 \mathrm{~km}^{2}\right)$ of Wyoming, USA. Great Divide South included all of GMU 301 north of United States Highway 40 and approximately $20 \%$ of GMU 3 along the border of GMU 301.

All sites were $>25 \mathrm{~km}$ apart except for Great Divide South and Great Divide North, which were $1 \mathrm{~km}$ apart in places. Vegetation communities on Blue Mountain, Great 


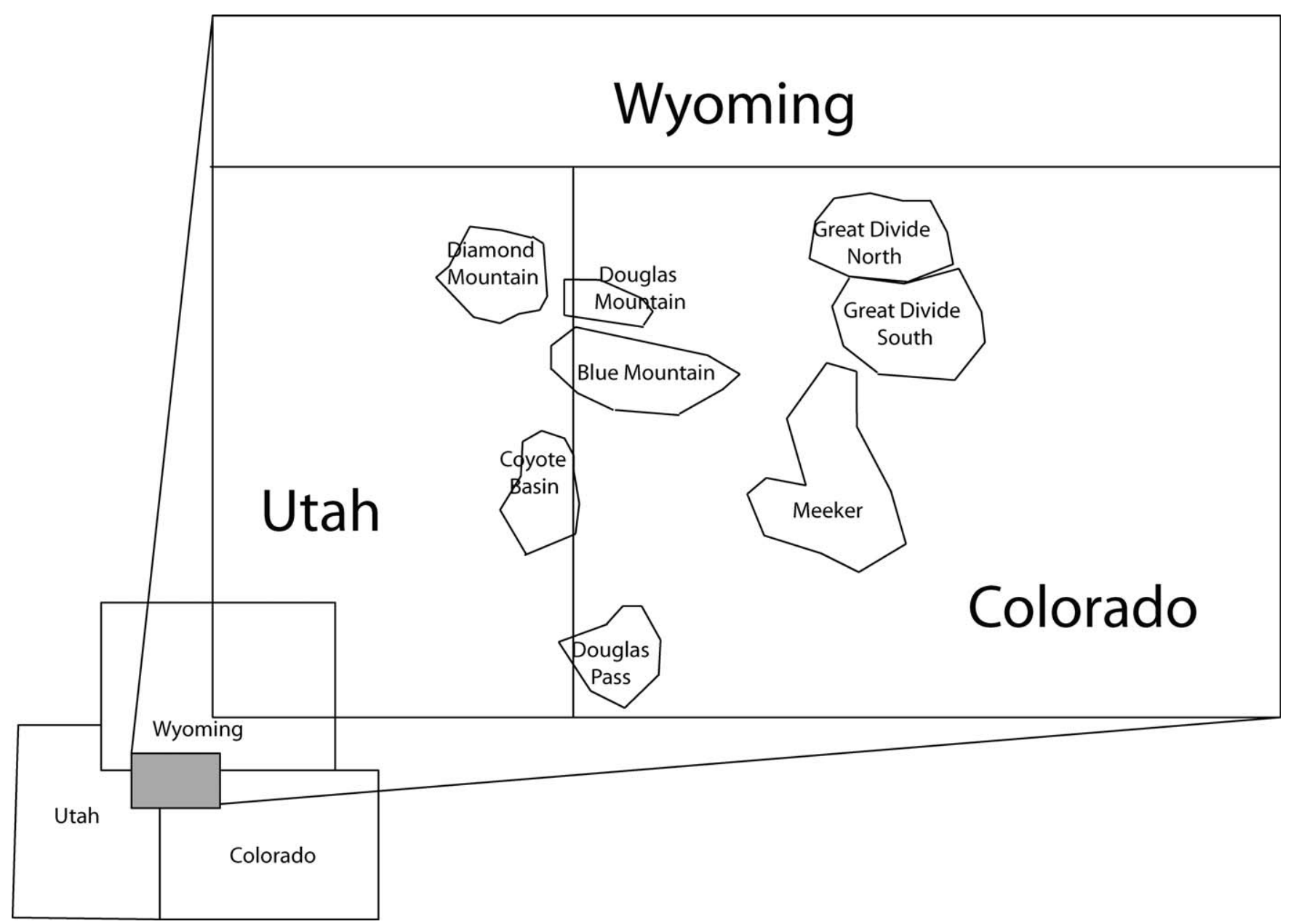

Figure 1. Map showing the location of our 8 study sites in Utah and Colorado, USA, where we studied the effects of coyote removal in $2003-2004$.

Divide, and Diamond Mountain were mostly sagebrush (Artemisia spp.), although Blue Mountain and Diamond Mountain also had areas with conifer (Picea spp. and Pinus spp.) and aspen (Populus tremuloides) forests. Coyote Basin was an arid lowland area dominated by sparse sagebrush habitat and some juniper (Juniperus spp.). For the Meeker site, areas adjacent to the eastern border of GMU 11 were mainly composed of sagebrush and grassland mixed with juniper woodland. Meeker also included the White River and its riparian corridor with a mix of agriculture, willows (Salix spp.), and cottonwoods (Populus spp.) on the southern border of GMU 11. The dominant vegetation community on Douglas Mountain and Douglas Pass was mixed conifer and aspen forest interspersed with open area dominated by sagebrush. Dominant land use was for summer grazing by livestock.

\section{METHODS}

\section{Predator Removal}

Wildlife Services conducted coyote control throughout the year at various levels (Table 1) within 6 sites (Diamond Mountain-Coyote Basin, Great Divide South, Great Divide North, Douglas Mountain, Meeker, and Blue Mountain) and did not implement it within one site (Douglas Pass).
Wildlife Services removed coyotes using a combination of methods including trapping, denning, ground shooting, M44 deployment, and aerial gunning from January through May. Wildlife Services provided us with the number of coyotes taken and 3 measurements of control effort: hours spent hunting from fixed-wing airplanes or helicopters, number of hours a WS employee spent hunting or trapping on the ground, and total hours worked (aerial hunting and ground hunting combined) for each site during 2003 and 2004.

\section{Road Surveys}

We conducted herd composition counts using the method explained in Connolly (1981) and Lopez et al. (2004). Surveys were conducted each month from July to December on 6 sites during 2003 and on 7 sites during 2004 (the Meeker site was not surveyed during 2003). All surveys were conducted by the same person over the same transect. We conducted surveys using a motor vehicle on roads in the morning (from dawn to $2 \mathrm{hr}$ after dawn) and evening (from $2 \mathrm{hr}$ before sunset until $30 \mathrm{~min}$ after it). Survey speeds ranged from $40 \mathrm{~km}$ to $70 \mathrm{~km}$, and transects averaged $60 \mathrm{~km}$ in length. We drove all roads in the study area, but some high-elevation roads were not surveyed in late fall because they were closed by state highway departments when they 
Table 1. Coyote control success (coyotes taken) and effort (hr worked) at each site in Utah and Colorado, USA, during 2003 and 2004.

\begin{tabular}{|c|c|c|c|c|}
\hline \multirow[b]{2}{*}{ Site-yr } & \multirow[b]{2}{*}{ Coyotes taken } & \multicolumn{3}{|c|}{ Hr worked } \\
\hline & & Total & Ground & Aerial \\
\hline \multicolumn{5}{|l|}{2003} \\
\hline Diamond Mountain & 27 & 202 & 190 & 12 \\
\hline Blue Mountain & 74 & 295 & 274 & 21 \\
\hline Douglas Mountain & 1 & 8 & 7 & 1 \\
\hline Great Divide North & 16 & 38 & 30 & 8 \\
\hline Great Divide South & 194 & 260 & 176 & 84 \\
\hline Douglas Pass & 0 & 0 & 0 & 0 \\
\hline \multicolumn{5}{|l|}{2004} \\
\hline Diamond Mountain & 112 & 92 & 68 & 24 \\
\hline Blue Mountain & 64 & 48 & 40 & 8 \\
\hline Douglas Mountain & 18 & 20 & 10 & 10 \\
\hline Meeker & 105 & 229 & 192 & 37 \\
\hline Great Divide North & 51 & 55 & 30 & 25 \\
\hline Great Divide South & 213 & 390 & 304 & 86 \\
\hline Douglas Pass & 0 & 0 & 0 & 0 \\
\hline
\end{tabular}

became impassable due to snow drifts. When we spotted an ungulate group ( $\geq 1$ animal), we recorded the number of ungulates, species, time, odometer reading, Global Positioning System location, distance and direction from observers, habitat, and behavior. Density indices (ungulates $/ \mathrm{km}$ and offspring:F ratios [offspring/100 F]) were calculated from road surveys.

\section{Hunter Harvest}

Prior to our study (2000-2002), the CDOW and UDWR issued an annual mean of 3,756 deer and 1,220 pronghorn permits for areas included in our study sites, and this resulted in a mean annual harvest of 2,703 deer and 1,033 pronghorn. During our study (2003 and 2004), the state wildlife agencies issued an annual mean of 4,574 deer and 475 pronghorn permits for our study sites resulting in an annual harvest of 3,260 deer and 403 pronghorn. Similar levels of coyote control were employed within our study sites prior to and during our study.

\section{Data Analysis}

We used a double-blind experimental design. We did not have access to WS control effort or success data until we completed all ungulate surveys. We did not share ungulate data with WS. At the end of the experiment, we gave WS the boundaries of our 7 study sites, and they provided the information requested.

We hypothesized that the no residual effects of predators would exist from one year to the next and that coyote densities at the start of each year would be similar for all sites regardless if control was conducted the prior year (Knowlton et al. 1999, Wagner and Conover 1999, Conover 2002). Therefore, we considered our experimental unit for data analysis to be a site-year $(n=13)$.

Independent data included amount of control effort by WS (hr spent hunting) and success (no. of coyotes killed) at each site. Dependent data included offspring:female ratios and density indices for mule deer and pronghorn (i.e., ungulates/ $\mathrm{km}$ traveled). For each site, we averaged ungulate data collected monthly to obtain a single value for each dependent variable. We compared offspring:female ratios and ungulate density indices to coyote control data (i.e., no. of coyotes taken, total hr worked, aerial $\mathrm{hr}$ worked, and ground $\mathrm{hr}$ worked) within site using simple linear regressions (PROC REG; SAS Institute 2001). All statistical tests were considered significant if $P \leq 0.05$.

\section{RESULTS}

\section{Coyote Control}

Wildlife Services personnel spent a mean of 126 hours ( $\mathrm{SE}=$ 37) annually controlling coyotes at each site (Table 1). This included a mean of 24 hours $(\mathrm{SE}=8)$ of aerial gunning and 102 hours $(\mathrm{SE}=31)$ using someone on the ground either shooting or trapping predators. A mean of 67 coyotes $(\mathrm{SE}=$ 20) were killed per site. Aerial gunning was the most productive method, taking $79 \%$ of all coyotes with only $19 \%$ of the man-hours. Most coyote control effort $(75 \%$ of $\mathrm{yr}-$ long take) occurred from January through May on all sites.

\section{Effect of Coyote Control on Ungulates}

Across all sites, we observed a mean of 2.5 mule deer/ transect $\mathrm{km}(\mathrm{SE}=0.5)$ and 3.3 pronghorn $/ \mathrm{km}(\mathrm{SE}=1.0)$. We recorded a mean of 44.9 mule deer offspring/100 females ( $\mathrm{SE}=4.2)$, and a mean of 54 pronghorn offspring/ 100 females $(\mathrm{SE}=5.4)$. For mule deer, offspring/female ratios were unrelated to the number of coyotes taken at each site $\left(R^{2}=0.18, F=2.41, P=0.15\right)$, total hours worked $\left(R^{2}=0.28, F=4.18, P=0.07\right)$, or hours worked aerial gunning $\left(R^{2}=0.26, F=3.88, P=0.07\right)$. Likewise for pronghorn, offspring/female ratios were not related to the number of coyotes taken $\left(R^{2}=0.07, F=0.44, P=0.53\right)$, total hours worked $\left(R^{2}=0.34, F=3.10, P=0.13\right)$, or hours worked aerial gunning $\left(R^{2}=0.35, F=3.21, P=0.12\right)$. However, number of coyotes taken, total number of hours worked, number of aerial hours worked, and number of ground hours worked were all positively correlated with number of mule deer seen per kilometer traveled (Table 2). Additionally, number of coyotes taken and number of aerial hours worked were positively correlated with pronghorn seen per kilometer traveled (Table 2). Hours spent aerial 
Table 2. Simple linear regression of relationships between coyote treatment variables provided by United States Department of Agriculture, Animal Plant Health Inspection Services, Wildlife Services and ungulates per kilometer calculated from our surveys in Utah and Colorado, USA, $2003-2004$.

\begin{tabular}{|c|c|c|c|c|c|c|}
\hline \multirow[b]{2}{*}{ Treatment variable } & \multicolumn{3}{|c|}{ Mule deer/km } & \multicolumn{3}{|c|}{ Pronghorn/km } \\
\hline & $R^{2}$ & $F$ & $P$ & $R^{2}$ & $F$ & $P$ \\
\hline Coyotes taken & 0.74 & 31.47 & $<0.001$ & 0.68 & 13.04 & 0.011 \\
\hline Hr worked & 0.46 & 9.21 & 0.011 & 0.35 & 3.18 & 0.125 \\
\hline Aerial hr worked & 0.60 & 16.42 & 0.002 & 0.84 & 31.08 & 0.001 \\
\hline Ground hr worked & 0.37 & 6.38 & 0.028 & 0.19 & 1.40 & 0.282 \\
\hline
\end{tabular}

gunning was autocorrelated with the number of coyotes taken $\left(r^{2}=0.92\right)$.

\section{DISCUSSION}

\section{Impact of Coyote Removal on Coyote Densities and Behavior}

Our study was unusual in that it was conducted at 7 different sites scattered across 2 states and because predator control was conducted over large areas $\left(>1,900 \mathrm{~km}^{2}\right)$. Often studies that have examined the impact of predator control programs have lacked replicates or failed because the areas from which predators were removed were too small.

We found that the number of hours spent aerial gunning on each site between January and May and the number of coyotes removed positively affected deer and pronghorn densities. Aerial gunning is considered highly efficient at targeting coyotes on winter territories (Gantz 1990, Wagner and Conover 1999). Our results support this. Most coyotes killed $(79 \%)$ were taken by aerial gunning while this activity only consumed $18 \%$ of all WS man-hours.

Coyote pairs with pups are more likely to kill sheep and lambs than nonbreeding coyotes (Knowlton 1972, Stoddart et al. 1989, Wagner and Conover 1999, Conover 2002), and only territorial coyotes breed and produce pups (Conner 1995, Sacks 1996). Territorial coyotes switch to larger prey when their pups are whelping in an effort to feed hungry pups, and this causes territorial coyotes to increase their killing of sheep and free-ranging ungulates (Knowlton 1972, Stoddart et al. 1989, Bekoff and Gese 2003). Preventive population reduction during winter and spring was found most effective for protecting livestock because territorial coyotes are most vulnerable during this period (Wagner and Conover 1999). Although vacant territories may be quickly reoccupied by transient coyotes, new residents will not have time to establish a territory and breed during that same year. Hence, preventive coyote control during winter and spring may reduce predation on livestock, deer, and pronghorn by reducing the number of pairs with pups rather than by reducing coyote densities.

Predator control within our study sites did not increase offspring survival based on offspring:female ratios. Hurley and Zager (2004) and Longhurst et al. (1952) also reported that predator control did not increase offspring:female ratios, suggesting that predators were not impacting offspring survival or predator control efforts were not intense enough to have an effect.
However, we found that mule deer and pronghorn densities were higher where coyotes had been controlled. Beasom (1974), Teer et al. (1991), and Smith and LeCount (1979) also reported that deer densities increased following exclusion or control of coyotes, and Smith et al. (1986) found that coyote control increased pronghorn densities.

Predator control may be ineffective when ungulate densities are not controlled by hunting or natural means (Teer et al. 1991) or when their populations are at or above carrying capacity (Ballard et al. 2001, 2003). Under such conditions, their densities may be controlled more by food availability or other limiting factors. At our study sites, both the UDWR and CDOW use hunting to keep mule deer and pronghorn populations at healthy levels. During 2000 to 2004, a mean of 2,926 mule deer and 781 pronghorn were harvested annually by hunters from within our study sites. Hence, we believe that mule deer and pronghorn populations were probably below carrying capacity at our study sites. This could explain why coyote control was successful during our study.

Several hypotheses may explain why coyote control can influence densities of deer and pronghorn but not offspring:female ratios. First, coyote control may effectively reduce coyote densities but coyotes killed equal numbers of ungulate offspring and adults and did not affect the offspring:female ratio. However, a plethora of literature summarized by deVos et al. (2003) indicates deer and pronghorn offspring are more vulnerable than adults to coyote predation, so this hypothesis seems unlikely.

Second, coyote control efforts may have been concentrated in areas where deer and ungulate densities were already high. In our study, coyote control was conducted to protect livestock from predators, not for wildlife protection. Hence, coyote control efforts were concentrated around ranches and livestock grazing areas. However, several studies have found that mule deer avoid areas with high cattle densities (Dusek 1975, Griffith and Peek 1989, Loft et al. 1991). Hence, we think that this is not a likely explanation for our findings.

Third, deer and pronghorn may have moved away from areas with high coyote densities to areas where coyotes were absent or scarce. Ungulates can recognize areas where predators are located by the predators' body odor, the odor of their feces and urine, the sight of them, the sound of their howls, and by interactions with them (Conover 2007). Moving to areas where predators pose less of a risk should increase survival of deer and pronghorn and their offspring, 
providing forage is of equal quality and quantity in coyotefree areas.

Other studies have also observed that free-ranging ungulates change their behavior, location, and habitat preferences to avoid the risk of predation. Geist (1981) reported that mule deer are sensitive to disturbance and cluster in areas where predators are rarely seen. Altendorf et al. (2001) found that mule deer alter their foraging behavior to minimize predation risk. Lingle (2002) demonstrated that avoidance of coyotes caused habitat segregation between mule deer and white-tailed deer (O. virginianus) with mule deer preferring to remain high on slopes and in rugged terrain whereas white-tailed deer preferred gentle terrain and to be low on slopes. Ripple and Beschta (2004) illustrated how avoidance of wolves (C. lupus) influenced spatial patterns of elk in Yellowstone National Park. Likewise, moose (Alces alces; Stephens and Peterson 1984), caribou (Rangifer tarandus; Bergerud 1985, Ferguson et al. 1988) and bighorn sheep (Ovis canadensis; Festa-Blanchet 1988) all moved away from areas where wolves or other predators were prevalent to sites where predators were less numerous even though these safer habitats often had lower quality forage.

If predator control is conducted in the same places annually (such as in our study), mule deer and pronghorn may have learned to move to these areas to avoid coyotes. Mule deer and pronghorn are wide-ranging animals. What we found may not have been a general increase in densities over a broad area due to coyote control, but rather local movements of ungulates into sanctuaries from predators created by WS coyote control efforts. Unfortunately, our data do not allow us to test which of these 3 hypotheses is correct, but we believe the third hypothesis is the most likely.

\section{MANAGEMENT IMPLICATIONS}

We found that preventive WS coyote removal for livestock protection was positively correlated with higher mule deer and pronghorn densities on our study sites. These results suggest that as coyote control increased so did the mule deer and pronghorn densities observed. Ranchers, who lease land to hunters, may receive more benefits from WS predator control activities than just livestock protection because higher deer and pronghorn densities should produce more income from hunting leases. Public land agencies also benefit when their management objectives are to increase densities of free-ranging ungulates. These benefits, however, will only last as long as the predator control program continues.

\section{ACKNOWLEDGMENTS}

This study was funded by the Colorado Division of Wildlife, Colorado Mule Deer Foundation, Jack H. Berryman Institute, and Utah Agricultural Experiment Station. We thank the United States Department of Agriculture, Animal Plant Health Inspection Services, Wildlife Services for allowing us access to their data. A. Brewerton, K. Frye,
E. Harrington, and A. Shafer helped collect ungulate data. We thank E. Harrington and R. Vail for their editorial help.

\section{LITERATURE CITED}

Altendorf, K. B., J. W. Laundre, C. A. Lopez, and J. S. Gonzalez. 2001. Assessing the effects of predation risk on foraging behavior of mule deer. Journal of Mammalogy 82:430-439.

Ballard, W. B., D. Lutz, T. W. Keegan, L. H. Carpenter, and J. C. deVos, Jr. 2001. Deer-predator relationships: a review of recent North American studies with emphasis on mule and black-tailed deer. Wildlife Society Bulletin 29:99-115.

Ballard, W. B., D. Lutz, T. W. Keegan, L. H. Carpenter, and J. C. deVos, Jr. 2003. Deer-predator relationships. Pages 177-218 in Mule deer conservation: issues and management strategies. Berryman Institute Press, Utah State University, Logan, USA.

Barrett, M. W. 1984. Movements, habitat use, and predation on pronghorn fawns in Alberta. Journal of Wildlife Management 48:542-550.

Beasom, S. L. 1974. Relationships between predator removal and whitetailed deer net productivity. Journal of Wildlife Management 38:854859.

Bekoff, M., and E. M. Gese. 2003. Coyote (Canis latrans). Pages 467-481 in G. A. Feldhamer, B. C. Thompson, and J. A. Chapman, editors. Wild mammals of North America: biology, management and conservation. Second edition. Johns Hopkins University, Baltimore, Maryland, USA.

Bergerud, A. T. 1985. Antipredator strategies of caribou: dispersion along shorelines. Canadian Journal of Zoology 63:1324-1329.

Conner, M. M. 1995. Identifying patterns in coyote predation on sheep on a northern California ranch. Thesis, University of California, Berkeley, USA.

Connolly, G. E. 1978. Predators and predator control. Pages 369-394 in J. L. Schmidt and D. L. Gilbert, editors. Big game of North America. Stackpole, Harrisburg, Pennsylvania, USA.

Connolly, G. E. 1981. Limiting factors and population regulation. Pages 245-285 in O. C. Wallmo, editor. Mule and black-tailed deer of North America. University of Nebraska, Lincoln, USA.

Conover, M. R. 2002. Resolving human-wildlife conflicts: the science of wildlife damage management. Lewis Brothers, Boca Raton, Florida, USA.

Conover, M. R. 2007. Predator-prey dynamics: use of olfaction. Taylor and Francis, Boca Raton, Florida, USA.

Denney, R. N. 1976. Regulations and the mule deer harvest: political and biological management. Pages 85-90 in G. W. Workman and J. B. Low, editors. Mule deer decline in the West: a symposium. Utah Agricultural Experiment Station, Logan, USA.

deVos, J. C., Jr., M. R. Conover, and N. E. Headrick. 2003. Mule deer conservation: issues and management strategies. Berryman Institute Press, Utah State University, Logan, USA.

Dusek, G. L. 1975. Range relations of mule deer and cattle in prairie habitat. Journal of Wildlife Management 39:605-644.

Ferguson, S. H., A. T. Bergerud, and R. Ferguson. 1988. Predation risk and habitat selection in the persistence of a remnant caribou population. Oecologia 76:236-245.

Festa-Blanchet, M. 1988. Seasonal range selection in bighorn sheep: conflicts between forage quality, forage quantity, and predator avoidance. Oecologia 75:580-586.

Fuller, A. 1998. A history of mule deer in northwestern Arizona. Proceedings of the Western Association of Fish and Wildlife Agencies 78:112-138

Gantz, G. F. 1990. Seasonal movement patterns of coyotes in the Bear River Mountains of Idaho and Utah. Thesis, Utah State University, Logan, USA.

Geist, V. 1981. Behavior: adaptive strategies in mule deer. Pages 157-223 in O. C. Wallmo, editor. Mule and black-tailed deer of North America. University of Nebraska, Lincoln, USA.

Gill, B. R. 2001. Declining mule deer populations in Colorado: reasons and responses. Colorado Division of Wildlife, Terrestrial Wildlife Research Special Report 77, Denver, USA.

Gregg, M. A., M. Brady, K. M. Kilbride, and M. R. Dunbar. 2001. Birth synchrony and survival of pronghorn fawns. Journal of Wildlife Management 65:19-24. 
Griffith, B., and J. M. Peek. 1989. Mule deer use of seral stage and habitat type in bitterbrush communities. Journal of Wildlife Management 53: 636-642.

Hurley, M., and P. Zager. 2004. Southeast mule deer ecology. Idaho Department of Fish and Game Project W-160-R-31, Subproject 51, Boise, USA.

Knowlton, F. F. 1972. Preliminary interpretations of coyote population mechanics with some management implications. Journal of Wildlife Management 36:369-382.

Knowlton, F. F., E. M. Gese, and M. M. Jaeger. 1999. Coyote depredation control: an interface between biology and management. Journal of Range Management 52:398-412.

Lingle, S. 2002. Coyote predation and habitat segregation of white-tailed deer and mule deer. Ecology 83:2037-2048.

Loft, E. R., J. W. Menke, and J. G. Kie. 1991. Habitat shifts by mule deer: the influence of cattle grazing. Journal of Wildlife Management 55:1626.

Longhurst, W. M., A. S. Leopold, and R. F. Dasmann. 1952. A survey of California deer herds, their ranges and management problems. California Department of Fish and Game Bulletin No. 6, Sacramento, USA.

Lopez, R. R., N. J. Silvy, B. L. Pierce, P. A. Frank, M. T. Wilson, and K. M. Burke. 2004. Population density of the endangered Florida key deer. Journal of Wildlife Management 68:570-575.

Mackie, R. J., D. F. Pac, K. L. Hamlin, and G. L. Dusek. 1998. Ecology and management of mule deer and white-tailed deer in Montana. Montana Fish, Wildlife and Parks, Wildlife Division, Federal Aid to Wildlife Restoration Report, Project W-120-R, Helena, USA.

Parsons, L. D. 1976. The mule deer are back. Proceedings of the Annual Conference of Western Association of State Game and Fish Commissioners 56:424-433.
Phillips, G. E., and G. C. White. 2003. Pronghorn population response to coyote control: modeling and management. Wildlife Society Bulletin 31: 1162-1175.

Ripple, W. J., and R. L. Beschta. 2004. Wolves and the ecology of fear: can predation risk structure ecosystems? BioScience 54:755-766.

Sacks, B. N. 1996. Ecology and behavior of coyotes in relation to depredation and control on a California sheep ranch. Thesis, University of California, Berkeley, USA.

SAS Institute. 2001. SAS software: usage and reference. Version 8.02. SAS Institute, Cary, North Carolina, USA.

Smith, R. H., and A. LeCount. 1979. Some factors affecting survival of desert mule deer fawns. Journal of Wildlife Management 44:381-388.

Smith, R. H., D. J. Neff, and N. G. Woolsey. 1986. Pronghorn response to coyote control一a benefit:cost analysis. Wildlife Society Bulletin 14:226231.

Stephens, P. W., and R. O. Peterson. 1984. Wolf-avoidance strategies of moose. Holarctic Ecology 7:239-244.

Stoddart, L. C., F. F. Knowlton, and R. J. Taylor. 1989. A first generation mathematical model for calculating area of influence and potential number of animals exposed to management programs. Vertebrate Pest Control and Management Materials 6:28-33.

Teer, J. G., D. L. Drawe, T. L. Blankenship, W. F. Andelt, R. S. Cook, J. G. Kie, F. F. Knowlton, and M. White. 1991. Deer and coyotes: the Welder experiments. Transactions of the North American Wildlife and Natural Resources Conference 56:550-560.

Wagner, K. K., and M. R. Conover. 1999. Effect of preventative coyote hunting on sheep losses to coyote predation. Journal of Wildlife Management 63:606-612

Associate Editor: Whittaker. 